\title{
Environmental radiation monitoring at the areas of the spent nuclear fuel and radioactive waste storage in the Russian Northwest
}

\author{
N. K. Shandala ${ }^{1}$, S. M. Kiselev ${ }^{1}$, M. K. Sneve ${ }^{2}$, V. A. Seregin ${ }^{1}$, \\ E. Shchelkanova ${ }^{3} \&$ G. M. Smith ${ }^{4}$ \\ ${ }^{1}$ Burnasyan Federal Medical Biophysical Centre, Russia \\ ${ }^{2}$ Norwegian Radiation Protection Authority, Norway \\ ${ }^{3}$ SevRAO Facility-1, Russia \\ ${ }^{4}$ GMS Abingdon Ltd, UK
}

\begin{abstract}
A big technical base of the Northern Fleet was created in the Russian Northwest in the 1960s at Andreeva Bay in the Kola Peninsula in the Barents Sea. It maintained nuclear submarines performing receipt and storage of radioactive waste (RW) and spent nuclear fuel (SNF). No further waste was received after 1985 and this technical base has since been re-categorized as a site of temporary storage (STS). In order to obtain comprehensive information with respect to current radiation circumstances at STS with regulatory purposes, radiationhygienic monitoring of the STS facility has been carried out. Environmental radiation monitoring demonstrated significant excess of ${ }^{137} \mathrm{Cs}$ and ${ }^{90} \mathrm{Sr}$ contents at local parts of the coastal strip of the STS health protection zone in seawater, seaweeds, bottom sediments and soil. The environmental radiation monitoring findings served as a basis for the associated databank arrangement.

Keywords: northern fleet, Andreeva Bay, storage of radioactive waste, spent nuclear fuel, environmental radiation monitoring, databank.
\end{abstract}

\section{Introduction}

Sites of temporary storage (STS) of spent nuclear fuel (SNF) and radioactive waste (RW) are located on the Kola Peninsula at Andreeva Bay (STSA) and at Gremikha village (STSG). STSA is the biggest site for SNF and RW storage; 
there is $1.3 \times 10^{16} \mathrm{~Bq}$ in SNF in the storage areas with 25 years storage duration and $6.6 \times 10^{14} \mathrm{~Bq}$ in RW. The main radionuclides are fission products ${ }^{137} \mathrm{Cs}$ and ${ }^{90} \mathrm{Sr}$. Current conditions of SNF and RW storage at STS have caused substantial degradation of some part of SNF during its storage. As a result, radionuclides have already penetrated into the soil near the storage areas at the depth of a few meters. The nearest settlements to STSA are: Nerpichiye village $(1.8 \mathrm{~km})$; Bolshaya Lopatka $(2.4 \mathrm{~km})$; and Zaozersk city $(8 \mathrm{~km}$ to east) where there are 15000 inhabitants. Norwegian Radiation Protection Authority (NRPA) carries out support of the Russian regulatory authorities with the purpose of increasing the effectiveness of activity directed to industrial projects implementation, meeting, at the same time, RF laws and taking into account international recommendations related to practicable operative methods suitable to RF actual circumstances. The principal objective of collaboration between NRPA and Federal Medical-Biological Agency (FMBA of Russia) is to ensure effective and efficient regulatory supervision of operations at STS falling into responsibility of FMBA of Russia. One of numerous problems was a problem review and collation of independent data on the radiation situation in areas on and around the STSs. In order to obtain comprehensive information with respect to current radiation circumstances at STS, specialists from Burnasyan Federal Medical Biophysical Center had some expedition examinations, in the course of which radiation-hygienic monitoring of STS facilities has been carried out. The objective was to gain a better understanding of the current radioactive contamination situation so as to support development of appropriate regulatory supervision of workers involved in STS remediation work and also to support the development of longer term management plans for the STSs from a regulatory point of view.

\section{Material and methods}

Points of monitoring were located in the Controlled Access Area (CAA), the Area of Radiation Safety Regime, the Health Protection Zone (HPZ), and Supervised Area (SA) of both STSs. More than 300 samples were being collected of environmental media and of local foodstuffs. The samples were being examined by means of gamma-spectrometry, radiochemical and radiometric methods.

In the course of gamma spectrometry analysis, the samples were put in 0.51 Marinelli glass. ${ }^{137} \mathrm{Cs}$ was being registered by $661.6 \mathrm{keV}$ line, while ${ }^{60} \mathrm{Co}-$ by $1170 \mathrm{keV}$ and $1330 \mathrm{keV}$ lines. ${ }^{90} \mathrm{Sr}$ was being identified using radiochemical method, according to the oxalate method [1] and method based on extraction with mono-iso-octyl ester of methyl-phosphonic acid of Yttrium-90 [2]. In personal dose monitoring (PDM), three types of detectors were in use -TLD$500 \mathrm{~K}$ detectors on the base of $\mathrm{Al}_{2} \mathrm{O}_{3}$ corundum and DTG-4 detectors based on lithium fluoride mono crystals in DTU cassettes, as well as PST detectors (glass thermo luminescent slab based on alumina phosphate glass) in IKS-A cassettes. 


\section{Results and discussions}

Methodological basis of this work is research radiation hygienic monitoring, which means performance of comprehensive dynamic observation and control of radiation hygienic situation nearby radiation hazardous facilities [3, 4]. Points for radiation hygienic monitoring were being selected and approved in-situ. These points were considered as reference points for long-term observation in the course of planned operations to remediate sites and buildings of the STS. The check points were selected in terms of plans on remediation of the STS sites and buildings, results of preliminary threat assessment and findings of laboratory radiation monitoring performed at the STS. ${ }^{137} \mathrm{Cs}$ and ${ }^{90} \mathrm{Sr}$ are the main dose forming radionuclide. Monitoring was being performed by all principal parameters specifying the environmental conditions (Table 1).

Table 1: The extent and frequency of the environmental media monitoring at Andreeva SevRAO facility.

\begin{tabular}{|c|c|c|c|c|}
\hline \multirow[t]{2}{*}{ Subject of monitoring } & \multicolumn{2}{|c|}{$\begin{array}{c}\text { Amount of check } \\
\text { points }\end{array}$} & \multicolumn{2}{|c|}{ Frequency of monitoring } \\
\hline & $\mathrm{HPZ}$ & $\mathrm{SA}$ & $\mathrm{HPZ}$ & SA \\
\hline $\begin{array}{l}\text { 1. Aerosols in } \\
\text { common air* }\end{array}$ & 4 & 1 & weekly & monthly \\
\hline 2. Precipitation** & 4 & 1 & weekly & monthly \\
\hline 3. Seawater* & 4 & - & weekly & - \\
\hline $\begin{array}{l}\text { 4. Aquatic organisms, } \\
\text { bottom sediments*** }\end{array}$ & 4 & - & annually & - \\
\hline $\begin{array}{l}\text { 5. Fresh water of } \\
\text { open ponds* }\end{array}$ & 1 & 2 & annually & annually \\
\hline $\begin{array}{l}\text { 6. Fresh water from } \\
\text { industrial water } \\
\text { pipeline* }\end{array}$ & 1 & & monthly & - \\
\hline 7. Soil $* * *$ & 8 & 3 & annually & annually \\
\hline 8. Vegetation $* * *$ & 2 & 3 & annually & annually \\
\hline $\begin{array}{l}\text { 9. Melted snow in } \\
\text { spring* }\end{array}$ & 3 & - & $\begin{array}{c}\text { April-May } \\
\text { weekly }\end{array}$ & - \\
\hline $\begin{array}{l}\text { 10. Water from } \\
\text { control boreholes* }\end{array}$ & 6 & - & monthly & - \\
\hline $\begin{array}{l}\text { 11. Control of gamma } \\
\text { and beta } \\
\text { radiation } * * * *\end{array}$ & 13 & 3 & monthly & monthly \\
\hline \multicolumn{5}{|c|}{$\begin{array}{l}\text { * Activity concentration and radionuclide composition. } \\
* * \text { Density of radioactive atmospheric fallout. } \\
* * * \text { Specific activity and radionuclide composition. } \\
* * * * \text { Gamma dose rate. Beta flux density. }\end{array}$} \\
\hline
\end{tabular}




\subsection{Characterization of the principal radiation situation parameters on the STS site at Andreeva Bay}

\subsection{1 $\gamma$ dose rate}

Gamma dose rate on the Andreeva STS site varies over the wide range: from 0.2 to $140 \mu \mathrm{Sv} / \mathrm{h}$. Maximum values here were observed near radiation hazardous facilities and in the area of the former brook mouth near Building 5. At the area of radiation safety regime - from 0.2 to $12 \mu \mathrm{Sv} / \mathrm{h}$. On the rest territory of $\mathrm{HPZ}$ and SA - from 0.063 to $0.14 \mu \mathrm{Sv} / \mathrm{h}$ at the average value of $0.12 \mu \mathrm{Sv} / \mathrm{h}$. Gamma dose rate off-site does not differ considerably from the levels typical for the territory of the Russian Northwest, in particular Murmansk region.

\subsubsection{Soil and vegetation}

Maximum levels of soil radioactive contamination on-site are observed at the area of old technological pier, as well as around some bildings, where content of ${ }^{137} \mathrm{Cs}$ reaches $5.7 \cdot 10^{7} \mathrm{~Bq} / \mathrm{kg}$, while content of ${ }^{90} \mathrm{Sr}$ is less by the order of magnitude. Content of ${ }^{137} \mathrm{Cs}$ and ${ }^{90} \mathrm{Sr}$ in soil off-site in HPZ and SA at the distance of more than $900 \mathrm{~m}$, is at the level of background values typical for uncontaminated territories of Russian North and does not exceed $36 \mathrm{~Bq} / \mathrm{kg}$ for ${ }^{137} \mathrm{Cs}$ and $4 \mathrm{~Bq} / \mathrm{kg}$ for ${ }^{90} \mathrm{Sr}$ (Table 2).

Table 2: $\quad$ Radionuclide contents in soil of the Andreeva STS.

\begin{tabular}{|c|c|c|c|}
\hline \multirow{2}{*}{ Place of measurement } & \multirow{2}{*}{ Radionuclide } & \multicolumn{2}{|c|}{ Specific activity, Bq/kg } \\
\hline & & Minimum & Maximum \\
\hline \multirow[t]{2}{*}{ CAA } & ${ }^{137} \mathrm{Cs}$ & 550 & $5,7 \cdot 10^{7}$ \\
\hline & ${ }^{90} \mathrm{Sr}$ & 64 & $5,7 \cdot 10^{6}$ \\
\hline \multirow{2}{*}{$\begin{array}{l}\text { HPZ }(500-900 \mathrm{~m} \text { from } \\
\text { CAA) }\end{array}$} & ${ }^{137} \mathrm{Cs}$ & 6 & 36 \\
\hline & ${ }^{90} \mathrm{Sr}$ & 2,9 & 4,0 \\
\hline \multirow[t]{2}{*}{ SA (1000 m from CAA) } & ${ }^{137} \mathrm{Cs}$ & 7,9 & 8,3 \\
\hline & ${ }^{90} \mathrm{Sr}$ & 1,8 & 3,2 \\
\hline \multirow{2}{*}{$\begin{array}{l}\text { SA-lake Podkova (3000 } \\
\text { m from CAA) }\end{array}$} & ${ }^{137} \mathrm{Cs}$ & 1,4 & 9 \\
\hline & ${ }^{90} \mathrm{Sr}$ & 1,2 & 3,1 \\
\hline Background & ${ }^{137} \mathrm{Cs}$ & \multicolumn{2}{|c|}{$1-50$} \\
\hline
\end{tabular}

${ }^{137} \mathrm{Cs}$ and ${ }^{90} \mathrm{Sr}$ ratio off-site, within $\mathrm{HPZ}$ and SA is higher than the ratio typical for global fallout, $1.5-2 .{ }^{137} \mathrm{Cs}$ and ${ }^{90} \mathrm{Sr}$ ration in the superficial soil covering on the STS site was 4 , and at up to $5 \mathrm{~m}$ depth this ratio was about 6 times lower $(0,71)$. This is evidence of intensive ${ }^{90} \mathrm{Sr}$ migration. Soil and vegetation contaminations are interrelated. According to Table 3 , the highest vegetation and soil contamination is typical for the CAA. Mean ${ }^{137} \mathrm{Cs}$ and ${ }^{90} \mathrm{Sr}$ contents in soil and in vegetation beyond CAA, i.e., beyond the industrial site is at the background level, typical for uncontaminated areas of the Russian North.

\subsubsection{Offshore waters}

Contents of ${ }^{137} \mathrm{Cs}$ and ${ }^{90} \mathrm{Sr}$ in Barents Sea are 0.04 and $0.03 \mathrm{~Bq} / \mathrm{l}$, respectively, that are more than an order of a magnitude higher, than average background 
values of these radionuclides concentrations, which, according to [5], are 0,006 $\left({ }^{137} \mathrm{Cs}\right)$ and $0,004 \mathrm{~Bq} / 1\left({ }^{90} \mathrm{Sr}\right)$. Concentration of ${ }^{137} \mathrm{Cs}$ in bottom sediments of the coastal stripe at the area of the former brook mouth is $100 \mathrm{~Bq} / \mathrm{kg}$ and $30 \mathrm{~Bq} / \mathrm{kg}$ behind the HPZ border that is considerably higher than background values. Content of ${ }^{90} \mathrm{Sr}$ in the same samples of bottom sediments varies from 36.6 to $2 \mathrm{~Bq} / \mathrm{kg}$ that is more than 20 times higher than background (Table 4). Contents of ${ }^{137} \mathrm{Cs}$ and ${ }^{90} \mathrm{Sr}$ in seaweeds during 8 years are few times higher than background values (Table 5).

Table 3: $\quad$ Radionuclide contents in vegetation of the Andreeva STS.

\begin{tabular}{|c|c|c|c||}
\hline \multirow{2}{*}{ Place of measurement } & \multirow{2}{*}{ Radionuclide } & \multicolumn{2}{|c|}{ Specific activity, Bq $/ \mathrm{kg}$} \\
\cline { 2 - 4 } & & Minimum & Maximum \\
\hline \multirow{2}{*}{ CAA } & ${ }^{137} \mathrm{Cs}$ & $4,7 \cdot 10^{3}$ & $4,7 \cdot 10^{3}$ \\
\cline { 2 - 4 } & ${ }^{90} \mathrm{Sr}$ & & 4,4 \\
\hline \multirow{2}{*}{$\begin{array}{c}\mathrm{HPZ}-(500-900 \mathrm{~m} \text { from } \\
\text { CAA })\end{array}$} & ${ }^{137} \mathrm{Cs}$ & 1,0 & 12,7 \\
\cline { 2 - 4 } & ${ }^{90} \mathrm{Sr}$ & 0,7 & 8,6 \\
\hline \multirow{2}{*}{$\mathrm{SA}(1000 \mathrm{~m}$ from CAA) } & ${ }^{137} \mathrm{Cs}$ & $<3$ & 7,6 \\
\cline { 2 - 4 } & ${ }^{90} \mathrm{Sr}$ & 0,66 & 9 \\
\hline $\begin{array}{c}\text { SA-lake Podkova (3000 } \\
\text { m from CAA) }\end{array}$ & ${ }^{137} \mathrm{Cs}$ & 0,93 & \multicolumn{2}{|c|}{} \\
\hline
\end{tabular}

Table 4: $\quad{ }^{90} \mathrm{Sr}$ and ${ }^{137} \mathrm{Cs}$ contents in marine environmental media near the SNF and RW STS, (Bq/kg).

\begin{tabular}{||c|c|c|c|c|c||}
\hline \multirow{2}{*}{ Area } & Sampling area & \multicolumn{2}{|c|}{$\begin{array}{c}\text { Bottom } \\
\text { sediments }\end{array}$} & \multicolumn{2}{c||}{ Seaweeds } \\
\cline { 3 - 6 } & ${ }^{90} \mathrm{Sr}$ & ${ }^{137} \mathrm{Cs}$ & ${ }^{90} \mathrm{Sr}$ & ${ }^{137} \mathrm{Cs}$ \\
\hline $\begin{array}{c}\text { Health } \\
\text { Protection } \\
\text { Zone }\end{array}$ & $\begin{array}{c}\text { Former brook } \\
\text { mouth }\end{array}$ & 36.6 & 100 & $\begin{array}{c}690 \\
9.4\end{array}$ & $\begin{array}{c}56.3 \\
24,5\end{array}$ \\
\hline $\begin{array}{c}\text { Supervised } \\
\text { Area }\end{array}$ & $\begin{array}{c}\text { In 5 m from the } \\
\text { coastal stripe }\end{array}$ & 2.0 & 30.0 & 0.75 & 1.77 \\
\hline
\end{tabular}

Table 5: Dynamics of the radionuclide specific activity variation in seaweeds of Motovsky Bay of the Barents Sea.

\begin{tabular}{||c|c|c|c|c||}
\hline \multirow{2}{*}{ Radionuclide } & \multicolumn{4}{|c||}{ Specific activity, Bq/kg } \\
\cline { 2 - 5 } & 1997 & 2004 & 2005 & 2008 \\
\hline${ }^{137} \mathrm{Cs}$ & 467 & 77 & 20 & 23 \\
\hline${ }^{90} \mathrm{Sr}$ & $3-2377$ & 231 & 210 & 19 \\
\hline \multicolumn{3}{|c|}{ Background content: ${ }^{137} \mathrm{Cs} \sim 20 \mathrm{~Bq} / \mathrm{kg} ;{ }^{90} \mathrm{Sr} \sim 0,2-3 \mathrm{~Bq} / \mathrm{kg}$} \\
\hline
\end{tabular}




\subsubsection{Foodstuffs}

The population of Zaozersk eats imported foodstuffs, except for wild berries, mushrooms, fish and drinking water. Specific activities of ${ }^{137} \mathrm{Cs}$ and ${ }^{90} \mathrm{Sr}$ in local foods (berries, mushrooms, sea fish), collected within SA, off-site STS, do not exceed actual permissible radiation-hygienic norms, except for mushrooms collected at CAA (table 6). Contents of ${ }^{137} \mathrm{Cs}$ and ${ }^{90} \mathrm{Sr}$ in drinking water used onsite, are 0.02 and $0.001 \mathrm{~Bq} / 1$, respectively, that are from 550 to 5000 times less than permissible levels for ${ }^{137} \mathrm{Cs}$ and ${ }^{90} \mathrm{Sr}$., which are $11 \mathrm{~Bq} / 1$ for ${ }^{137} \mathrm{Cs}$ and $5 \mathrm{~Bq} / 1$ for ${ }^{90} \mathrm{Sr}$, according to [6] (table 6).

Table 6: $\quad$ Specific activities in sea fish, wild berries and mushrooms nearby the Andreeva STS.

\begin{tabular}{|c|c|c|c|c|c|}
\hline \multirow{2}{*}{$\begin{array}{l}\text { Type of } \\
\text { sample }\end{array}$} & \multirow[t]{2}{*}{ Place of sampling } & \multicolumn{2}{|c|}{$\begin{array}{l}\text { Specific activity, } \\
\mathrm{Bq} / \mathrm{kg}\end{array}$} & \multicolumn{2}{|c|}{$\begin{array}{l}\text { Permissible } \\
\text { activity, Bq/kg }\end{array}$} \\
\hline & & ${ }^{137} \mathrm{Cs}$ & ${ }^{90} \mathrm{Sr}$ & ${ }^{137} \mathrm{Cs}$ & ${ }^{90} \mathrm{Sr}$ \\
\hline \multirow[t]{2}{*}{ Mushrooms } & SA & 34,2 & 17,2 & \multirow{4}{*}{500} & \multirow{4}{*}{50} \\
\hline & CAA & $2,6 \cdot 10^{3}$ & 49,6 & & \\
\hline \multirow[t]{2}{*}{ Mushrooms } & $\begin{array}{c}\text { SA (2 km from the } \\
\text { STS) }\end{array}$ & 5,88 & 1,3 & & \\
\hline & $\begin{array}{l}\text { SA (5 km from } \\
\text { Zaozersk) }\end{array}$ & 20,0 & 0,24 & & \\
\hline $\begin{array}{c}\text { Drinking } \\
\text { water }\end{array}$ & PHZ & 0.02 & 0.001 & 11 & 5 \\
\hline Cowberry & SA & 1,91 & 0,28 & 160 & 60 \\
\hline Fish & SA coastal stripe & $0,4-3,2$ & $0,6-1$ & 130 & 100 \\
\hline
\end{tabular}

\subsubsection{Databank development}

The environmental radiation monitoring findings served as a basis for the associated databank arrangement. Table 7 illustrates a volume of gathered information integrated into the database concerning to the radio-ecological monitoring.

The experimental results received have been plotted on the electronic maps of the place with different information layers (figs. 1-3).

Table 7: Radio-ecological monitoring data put in the database.

\begin{tabular}{|l|c|}
\hline \multicolumn{1}{|c|}{ NAME OF TABLE } & AMOUNT OF RECORDS \\
\hline DOSE RATE & 2010 \\
\hline DOSE RATE IN SOIL & 352 \\
\hline MUSHROOMS AND BERRIES & 15 \\
\hline MELTED SNOW WATER & 203 \\
\hline SOIL & 291 \\
\hline SOIL ACTIVITY & 381 \\
\hline GROUND WATER & 1532 \\
\hline VEGETATION & 40 \\
\hline
\end{tabular}




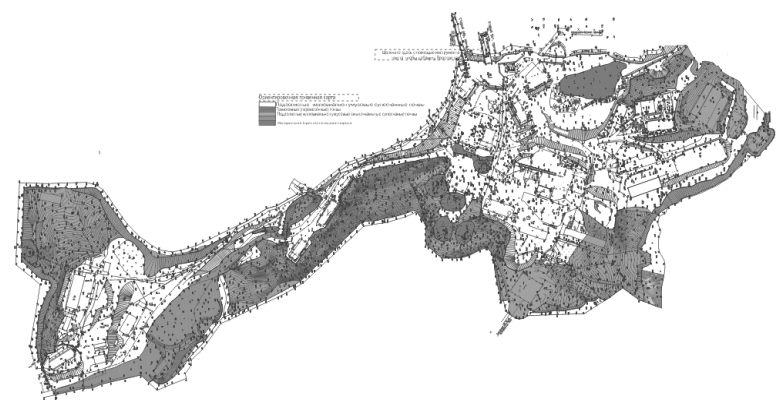

Figure 1: Example of the Soil Map (Andreva STS), integrated into the Databank.

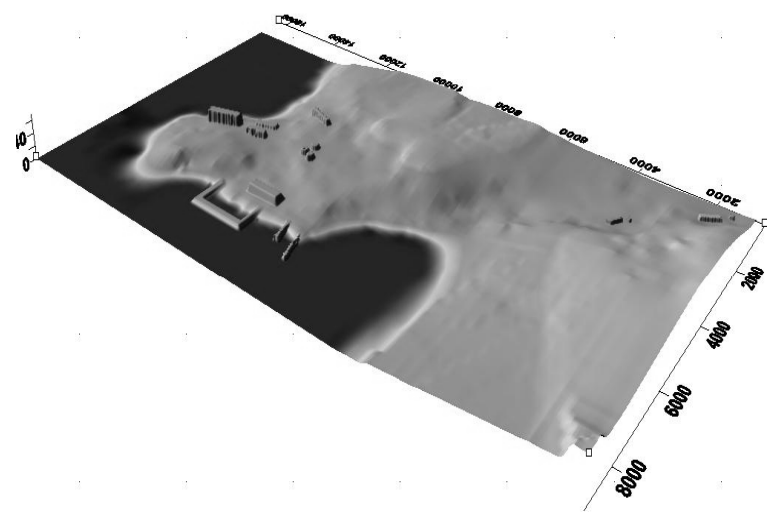

Figure 2: Example of the map of gamma dose rate distribution at the STS integrated into the Databank.

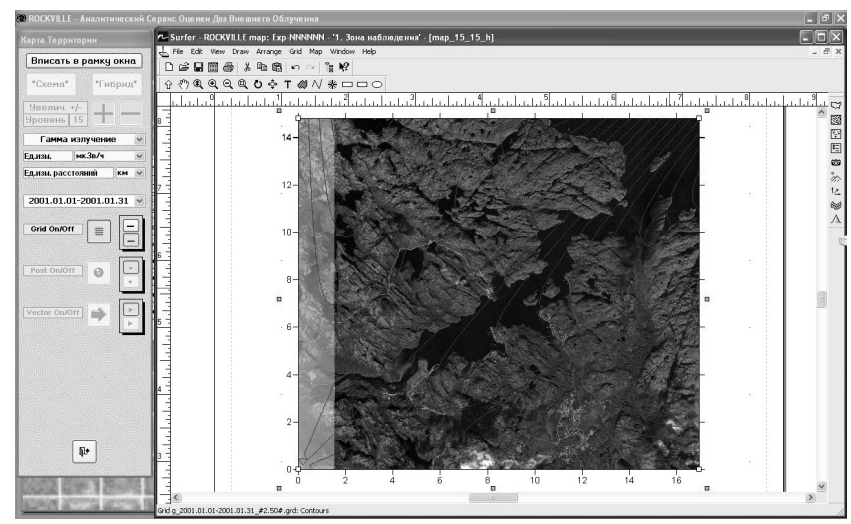

Figure 3: Information window DATABANK, demonstrating isolines of gamma dose rate in-situ. 
Further steps relate to generation of full geographic information system, which permits to carry out the computer calculation of the main indexes for simulation and prognosis of radio-ecological situation with the purpose of the radiation safety regulation.

\section{Conclusions}

Radiation hygienic monitoring served as a methodic basis for study of the current radiation situation at the HPZ and SA of the SNF and RW STS at Andreeva Bay over 2005-2008. The findings of such monitoring permitted to characterize the radiation hygienic situation at the HPZ and SA of the STS. Generally, the findings show that today, there is no significant impact of the STS inductrial site on the adjacent SA area, except for the marine environment at the offshore areas (bottom sediments, seaweeds). ${ }^{137} \mathrm{Cs}$ and ${ }^{90} \mathrm{Sr}$ contents in the environmental media of the SA and external gamma dose rate, in majority of cases, are at the background level. Radiation situation at the HPZ, on the industrial site, are specified by significant excess of some radiation hygienic terms. Therefore, special requirements are required on regulation under conditions of on-going wide-scale operations on remediation of the STS buildings, constructions and site. Taking regulatory measures is urgent to limit internal and external radiation exposure to workers. However, regulation of actions, performance of which will eliminate sources of environmental contamination and minimize risk of radioactivity penetration and spreading beyond the STS industrial site is also very important.

\section{References}

[1] Methodic Guidelines on Sanitary Control of Radioactive Substance Contents in Environmental Media. //A N Marej editor. M.: Institute of Biophysics MZ SSSR, 1980. - $336 \mathrm{p}$.

[2] Strontium-90. Identification in Foodstuffs //Methodic Guidance /MU 2.6.1.32-M., 2003. - $21 \mathrm{p}$.

[3] Introduction of radiation safety indexes with respect to the environmental conditions, including food raw materials and foodstuffs in the system of social hygienic monitoring //Methodic Guidelines. M.: Minzdrav of Russia, 2004. -24 p.

[4] Ilyin L A, Shandala N K, Savkin M N ea. Place and role of radiation hygienic monitoring in the system of social hygienic monitoring //Hygiene and Sanitary, 2004. - No 5. - p. 9-15.

[5] Brief annual information on radiation situation in the Russian Federation over 2004. Chief of UMZOC of polar, sea works and staffs of the Rishydromet V V Chelyukanov. - Moscow, 2004. - 11 p.

[6] Russian Radiation Safety Standards (NRB-99). - Ministry of Health of RF. Moscow (1999) (in Russian) - 115 pp 